\title{
Development of a Graphic Design Learning Module for the Deaf and Hard-of-Hearing (DHH) Students Based on Technology and Learning Style in Malaysian TVET institutions.
}

\section{Zainuddin Ibrahim ${ }^{1}$, Norlidah Alias ${ }^{2 *}$, Dorothy DeWitt ${ }^{3}$, Abu Bakar Nordin ${ }^{4}$,Khairul Azhar Jamaludin ${ }^{5}$ \&Hutkemri Zulnaidi ${ }^{6}$}

${ }^{1}$ Graphic Design \& Digital Media Department, Faculty of Arts and Design, UniversitiTeknologi MARA, 42300 Bandar PuncakAlam, Selangor, MALAYSIA

${ }^{2346}$ Department of Curriculum \& Instructional Technology, Faculty of Education, University of Malaya, 50604 Kuala Lumpur,MALAYSIA

${ }^{5}$ Centre of Education Leadership \& Policy, Faculty of Education, UniversitiKebangsaan Malaysia, 43600 Bangi, Selangor, MALAYSIA

drnorlidah@um.edu.my²

Article History: Received: 11 January 2021; Accepted: 27 February 2021; Published online: 5 April 2021

\begin{abstract}
Graphic Design is used in many industries and involves both the knowledge and skills in creating artefacts. Many Deaf and hard-of-hearing (DHH) students, especially in the Technical and Vocational Education and Training (TVET) institutions are attracted in pursuing studies in this field, perhaps due to the visual nature of the course. However, learning graphic design is challenging for DHH students due to the technologies and teaching approach applied in these institutions. A module which was designed with experts, was implemented in a selected polytechnic which offered the graphic design course for the deaf and non-deaf students. The module used videos and other resources for the different learning styles, as well as a discussion platform on Padlet, and quizzes. An exploratory implementation study on 15 DHH students who volunteered to use the module was conducted. The students' interactions were monitored and the results of their pre and post-tests during the implementation of the module was analysed to determine if the module was effective for learning. The findings indicate that students could use the module based on their learning styles and were active interacting on Padlet. The results of the pre and post-tests show a significant increase in scores, indicating the effectiveness of the module. Hence, the module has the potential to improve understanding in graphic design among DHH students. The findings have implications on the design of modules for DHH and special needs students. This is in line with TVET aspiration, which is to provide equal access to quality education for all. Further investigation should be done to determine whether the module could be used for other programs involving special needs students.
\end{abstract}

Keywords: graphic design, learning module, learning styles, deaf and hard-of-hearing, Padlet, interactive virtual wall.

\section{INTRODUCTION}

Graphic design has been influenced by advances in technology. As a subject, graphic design now includes disciplines such as motion graphics, environmental commodities, and new media, while as a profession it includes the movie industry, and all manner of visual communication and design, both online and offline, for creating useful and pleasing artefacts (Appiah \&Cronjé, 2014). In the graphic design programme, courses such as website design, animation and multimedia are offered in which the understanding and comprehension of the concepts as well as the development of skills are required (Ryan \& Conover, 2004).

However, according to International Labor Organization (ILO) (2012), most of the general educational programmes were struggling to design a sound curriculum for students with diasbailities. The lack of knowledge, understanding, andresouces in developing the inclusive curriculum has contributed to this issue. UNESCOUNEVOC (2019) believes that Technical Vocational Education and Training (TVET) institutions should be offered to all students, including students with diabilities. Therefore, transformation of TVET should consider a number of aspects such as: a) National legal framework, policy and strategy for inclusive TVET, b) curriculum, learning environment and assessment, and c) expertise of teachers and trainers to effectively deliver TVET for students with diasabilities (UNESCO-UNEVOC, 2019).

In Malaysia, there are more than 100 graphic design programmes offered by public and private institutions (Ministry of Higher Education, 2014). The Malaysian Qualification Agency's guidelines are used in developing the curriculum for these programmes. However, a review of these guidelines shows that the needs of DHH students or any special needs student, is not emphasized. The Malaysian Education Act (1961) did state that curriculum design should consider special needs the student. In addition, Salamanca Statement and Framework for Action on Special Needs Education (SNE) (UNESCO, 1994) and the National Education Blueprint (Ministry of Education, 2013) also emphasizes on the need for special education to be highlighted.

Graphic design courses seem to be popular among the DHH students in Malaysia. This may be because graphic design relies on visual channels of information. When 245 Malaysian students from 24 secondary schools catering to DHH in Malaysia were surveyed, many of them indicated they preferred to learn web design, animation and multimedia, which were aspects of graphic design (Zaharudin, Nordin\& Yasin, 2011). 
However, there are several issues faced by students when learning graphic design. As a subject, graphic design is difficult as students need to be innovative and see possibilities in using new knowledge to produce new products (Appiah \&Cronjé, 2014). Further, developing new ideas in graphic design has been aided by the use of cognitive tools which makes used of computer technology to generate ideas and use in design tasks (Appiah \&Cronjé, 2014). Ensuring a strong understanding of the concepts in graphic design is difficult for DHH students. DHH students may find technology tools challenging as some of the technology tools for teaching graphic design may not be tailored to the needs of the $\mathrm{DHH}$, and may even interfere with learning (Mayer, 2014). In addition, although technology such as videos can be useful as sign language interpreters are included to translate the content, these interpreters, are not experts in graphic design and some terminologies do not currently have standardized signs (Ibrahim, Alias \&Nordin, 2016). In addition, the technology tool and learning resource should be in line with the learning style of the students, so as not to distract from learning.

Hence, ensuring the right technology for DHH students is employed and ensuring that it is suitable with the students learning style (Graf, Kinshuk\& Liu, 2009), can ensure better understanding of the concepts. For this purpose, a Graphic Design Learning Module (GDLM) for learning with technology according to their specific learning style may provide the opportunity for DHH students to learn effectively (Felder \& Silverman, 1988; Spector, 2012).

\section{Inclusive TVET}

The Convention of Rights of Persons with Disabilities has recognized the rights for students with disbailities to receive an equal education opportunities (United Nations Committee on the Rights of Persons with Disabilities (UNCPRD, 2016). Even so, it is found that these students are still isolated and received poor education quality (UNCPRD, 2016). Realizing the importance of developing employability skills for all, TVET has included a number oftarget groups, including persons with disabilities (PWDs) and special education needs, to receive teaching and training in TVET institutions. According to UNESCO-UNEVOC (2019), there are seven threads to inclusive TVET: a) different interpretation of inclusive TVET, b) National legal frameworks and policies/strategies for inlusive TVET, c) inclusive learning environment, d) quality of teachers and trainers, e) roles of communities, parents and students, f) monitoring and evaluation, and g) transition to the labour market.

In ensuring a quality of inclusive TVET, Bowman and Callan (2012) has proposed a pedagogic framework for socially inclusive VET (refer Figure 1). In this framework, they mentioned that the social inclusion principles such as planning for sustainability, contextulizing training to suit local context, building partnership, developing tailored services and building partnership, should be the base for this framework. Also, the pedagogic principles such as learner-centredness, real world goal oriented, active learning, scaffolding and supported learning, flexible as well as sustainable learning should be considered first before designing the training curriculum.

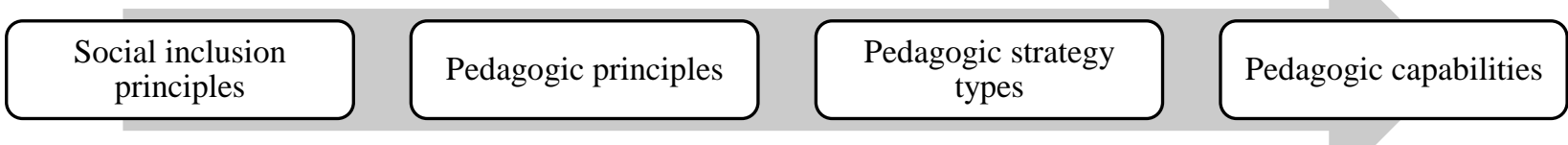

Fig. 1 - Pedagogic framework for socially inclusive VET

These principles are then translated into teaching strategies which focus on a number of aspects such as assessment and progression measures, learning content and delivery, learning environment, as well as learning engagement and persistence. Teachers or trainers on the other hand, play an important role in developing a more inclusive learning settings. For instance, they are expected to: a) have a high level of understanding of diversity in learning, b) understand students' background and capabilities, c) select and adapt suitable learning strategies, resources and matrials to support learning, and d) facilitate learning to its maximum potential.

\section{Technology for the $\mathrm{DHH}$}

Integrating technology in learning has a positive impact on DHH students' understanding. Interactive multimedia seems to offer better opportunities to improve understanding compared to conventional learning approaches (Mich, Pianta\& Mana, 2013). DHH students have limited hearing senses and instead, fully interact with visuals. In addition, visual presentations with technology seem to be more effective in assisting DHH students' understanding (Barca, Pezzulo, Castrataro, Rinaldi \& Caselli, 2013; Berent, Kelly, Schmitz \& Kenny, 2008; Narr\& Cawthon, 2011; Petrantonakis, Kosmidou, Nikolaraizi, Koutsogiorgu\&Hadjileontiadis, 2008). Although pictures, animations and videos can support text comprehension, many of the skills needed for integration of these media has not been adequately implemented at school (Verhoevan\&Graesser, 2008). 
Visual presentations using videos seem to be one of the best approaches because videos can be repeated and provides DHH students opportunity to understand deeply as they can repeat the lesson (Yong, 2007). Videos can be used but the DHH learner, may have to replace the missing audio element with subtitles or use the services of a sign language interpreter (Al-Rousan, Assaleh\&Tala'a, 2009; Debevc, Milošević\&Kožuh, 2015).

Some researchers have developed specific software to give DHH students the same opportunity to learn as hearing students (Knoors\&Marschark, 2014). According to Bottoni, Capuano, De-Marsico, Labella, and Levialdi (2011), production of multimedia material by the DHH-Centred Learning Environment (DALE) has helped DHH students in overcoming learning difficulties. DALE is a multimedia learning platform, which is based on the concept of storytelling and likeness (storytelling and conceptual metaphors), and cognitive embodiment adopted as a framework for the course in the form of sensory materials.

Instant messaging systems have been used to communicate with deaf and hearing students (Blom, Marschark, Vervloed\&Knoors, 2014; Nagalingam, 2008). In addition, digital sign language, which uses a special software to interpret language into sign language to enable non-signing instructors to teach DHH students can be used to enhance the performance and understanding of DHH students as their communication issue is resolved (Lim, 2008). In Intelligent Thai, text is translated to the Thai sign language for learning (Dangsaart, Naruedomkul, Cercone \&Sirinaovakul, 2008), using multimedia application to change the text or voice to an animated sign language (Stewart, Allan. Harrison, 2010; El Ghoul \&Jemni, 2009). However, there is still limited multimedia software for DHH students (Knoors\&Marschark, 2014). Further, research into the educational efficacy of software among DHH students is also lacking (Stinson, 2010).

Some studies have shown that e-learning has the possibility of improving learning for DHH students. This has been suggested by Chowdhuri, Parel, and Maity (2012) who agreed that DHH students should not be excluded from the e-learning approach. On the other hand, the use of e-learning may be mainly used for delivery of lecture notes.

Hence, web 2.0 (Vrettaros, Argiri, Stavrou, Hrissagis\&Drigas, 2010) and the use of videos (Debevc, Kosec\&Holzinger, 2010) have helped DHH students to learn. These different forms of instruction, and multimedia have the potential to enable learning (Verhoeven, Schnotz\& Pass, 2009). Hence, it is important to explore how learning environments can be designed for DHH students to advantage of them (Verhoeven \&Graesser, 2008, Verhoeven, Schnotz\& Pass, 2009). Most of the research using technology have only focussed on the areas of language, and research in use of technology for the DHH in graphic design is still lacking. Hence, as the hearing-impaired students have difficulties completing their tertiary level studies because of difficulties in comprehension (Bueno, Fernández del Castillo, Garcia \& Borrego, 2007), more studies are needed in this area.

\section{DHH Students' Processing Multimedia}

Sign language is important for communication with DHH students. Before the internet era, communication with the DHH was restricted to certain times and places because the DHH needed face-to-face interaction (Valentine \& Skelton, 2008). However, now DHH students frequently use digital media and the internet to communicate and maintain social relations (Barak \&Sadovsky, 2008). The processes that are involved in using different media may assist or interfere with learning among the DHH.

Visual and verbal information are processed in separate information processing systems (Bower, 2017; Mayer, 2014). Words and sounds are processed in the auditory working memory, and written text and images are in the visual working memory (Mayer, 2014). While hearing students can make use of both auditory and visual working memory for better understanding, DHH students are limited to only the visual working memory. As humans have a limited information processing capacity, there is a higher possibility of a cognitive load when only one channel is used (Bower, 2017; Mayer, 2014). Hence, DHH students have more opportunities for interference due to cognitive overload of the visual channel.

Animations are more challenging to process. While a static picture only has visuospatial information, animation entails temporal information (Hall \& Bavelier, 2010). Hence, there is a higher cognitive load for DHH students when animations need to be processed in their limited working memory. Further, according to the dual-coding theory, redundancy should be avoided as pictures and text may interfere with learning as they involve the same sensory processes (Paivo, 1986). The addition of pictures also can lead to more superficial processing when accompanied by text. Similarly, animation typically does not contribute to enhance learning especially when the information is relatively abstract (Rasch \&Schnotz, 2009).

Other aspects in the display of text can affect learning. The size of font should be large enough to facilitate reading and not contribute to cognitive overload reading (Kuiper, Volman\&Terwel, 2005; Mayer, 2014). Information should preferably be in hypermedia format as hypermedia or hypertext will allow DHH students to move from one content to another via links (DeStefano \& LeFevre, 2007). However, this is only helpful for DHH students who have sufficient prior knowledge and mastery of functioning skills to support use of the hyperlinked materials. Lower ability and knowledge DHH students will need more guidance and proper instruction from the beginning of the lesson in order to use hyperlinked materials (Knoors\&Hermans, 2010; Marschark, Sapere, Convertino\&Pelz, 2008). Hence, a text link may be better than sign link because sign links are too complex (Fels, Richards, Hardman \& Lee, 2006). 
Hence, as visual information display has potential to affect learning, it can be made effective depending on the individual learner's learning style (Mayer, 2003). Some learning styles require verbal information to be processed rather than visual information. Hence, for the design of a learning module for the DHH, the sign and text language used should be adapted according to the user needs and learning style.

\section{Learning Styles}

Identifying the uniqueness of learning style is important to encourage students' involvement in the learning process (Graf, Kinshuk\& Liu, 2009; Larkin-Hein \&Budny, 2001; Naimie, Siraj, Abuzaid, \&Shagholi, 2010; Yang \& Tsai, 2008). The outcome from previous research indicated that teaching according to the learning styles of the student has helped to increase students' performance and boost their motivation to learn (Aviles \& Moreno, 2010; Franzoni\& Assar, 2009; Saeed, Yang \&Sinnapan, 2009).

Felder and Silverman (Felder \&Soloman, 1988) introduced a model of learning that focuses on learning styles. There are four dimensions of learning styles: Processing (Active/Reflective), Perception (Sensing/Intuitive), Input (Visual/Verbal) and Understanding (Sequential/Global) assembles the learning preferences and provides insight into how teaching strategies can modify to broaden DHH student understanding. They developed the psychometric assessment instrument, Index of Learning Styles (ILS) (Felder \&Soloman, 1988). This index determines four dimensions of learning style and consists of 11 questions for each dimension. The highest score of any section indicates the type of student's learning styles.

There has been concern regarding the DHH students' learning styles. It is believed that DHH students have different personalities and different learning styles from hearing students (Slavin, 1994). Every DHH student is born with a distinctive learning style (Gregore, 1985). Identifying students' learning styles is important to ensure the optimum learning occurs (Graf, Kinshuk\& Lin, 2009; Larkin-Hein \&Budny, 2001; Naimie et al., 2010; Yang \& Tsai, 2008). Past research showed that learning content based on ones' learning styles can enhance students' performance and motivation. Learning based on ones' preferred learning styles allows students to focus, understand and remember better (Dunn \& Dunn, 1978). DHH student has a different learning style (Knoors\&Marschark, 2014). Despite the importance of learning styles, few studies have been done on it (Pashler, McDaniel, Rohrer \& Bjork, 2008). Learning through appropriate learning styles has positive impact on students (Alias, 2010). However, there seems to be lack of emphasis on the use of technology and learning styles among DHH students learning graphic design. Students are not given opportunities to learn using their preferred learning styles (Pashler et al., 2008). The learning needs among DHH students needs to be investigated further (Alias, Alias, Ibrahim, Atan\& Kadir, 2012).

Although, learning styles have been used among learners in many subject areas, it does not seem to have been used among DHH students, and especially in graphic design. More exploratory implementation studies are needed to investigate the potential of different learning and instruction which may encourage the use of technology and learning styles. This study is a single case in a specific cultural context but the findings of this study may assist in the implementation of graphic design programmes in other institutions.

Although there have been some studies which have focused on language development to enable effective communication among DHH students, studies using technology and learning styles among DHH students, and more so for graphic design programmes are limited. Hence, this study seeks to bridge the gap by contributing to the existing body of research on the development of the GDLM based on technology and learning styles for DHH students in a polytechnic.

\section{Purpose of the Study}

This exploratory implementation study was to determine whether the GDLM based on technology and DHH students' learning styles would improve the DHH learners' comprehension of the graphic design topics in a selected polytechnic. The research questions are:

1. How is the GDLM based on technology and learning styles used by the DHH students in the context of the study?

2. How effective is the GDLM for learning the topics among the DHH students in the context of the study?

\section{Research Design}

This study is an exploratory implementation study which focuses on evaluation of the GDL module designed (DeWitt, Alias, Siraj, 2014). The module on animated graphics was selected to be implemented at a polytechnic which catered to DHH students. Since TVET institutions are aimed at providing quality learning for PWDs, this study specifically selected DHH students from a Malaysian TVET institution. The selected institution had a multiracial composition of Malaysian students who were DHH as well as non-DHH. The participants selected were students in the third semester who were DHH and registered in the graphic design programme at the institution. Ethical consent was obtained from the institution to request for volunteers. A class of $15 \mathrm{DHH}$ students volunteered to participate in the study. A survey of the participants indicated that the majority (98\%) use the Malaysian Sign Language for communicating. 


\section{The Graphic Design Learning Module (GDLM) based on technology and learning styles}

The GDLM was designed with a panel of 24 experts comprising of experts in graphic design, educational technology, professionals involved in the field of hearing disabilities, policy-makers from the Ministry of Education and academics in higher education. These experts gave their input on the design to determine the objectives, instructional strategies, and delivery of the module. Their input was based on the theories and instructional model identified.

\section{Objectives}

Consensus was determined between the graphic design experts and the professionals in hearing disabilities to ensure that the objective of the module could encompass the understanding of the theories, concept and development of graphic animation by students. The topics were determined according to the standards required of the programme by the polytechnic and consisted of introduction of graphic animation, graphic animation framework, graphic animation composition, create graphic animation and graphic animation documentation. Specific activities were identified based on the topics.

\section{Learning environment}

The module was delivered through a web-based platform, WordPress, and comprised of guidelines, interactive content and media, and activities for students to learn. All the content and activities were designed based on the learning styles suitable for the $\mathrm{DHH}$, which was more visual in nature. The media included high-quality videos with sign language for every topic. A Malaysia Sign Language interpreter was employed for the videos as the content was in the national language, Malay. Videos were also an advantage as the learners could repeat watching the videos for better understanding.The GDLM was interactive as participants could interact with the videos, quizzes as well as an interactive virtual wall for discussion. The discussion forum, consisted of an embedded link to Padlet, an interactive virtual wall (DeWitt, Alias, Ibrahim, Ngu\&Mohd. Rashid, 2015). This enabled learners to post their response to the questions provided. This feature of discussion was provided for every topic in the learning module and the learners could post text, graphics and videos links. The discussion was moderated by the instructor, who would also respond to students queries. In order to test their understanding, students needed to answer all the questions in an online quiz. There were 10 questions for the five topics in the quiz. Feedback on the results will be given immediately after completion of the quiz.

\section{The Research Procedure}

Before the implementation of the module, the participants had to determine their learning style using the Index of Learning Styles (ILS) (Felder \&Soloman, 1988). The participants would then be given the GDLM appropriate to their learning style. The module could be accessed online, or used at the polytechnic or at home on students' desktop computers or laptops.

During the implementation, a facilitator would moderate the learning process and provide scaffolding for the students. The students had to register to use Padlet and participate in the discussions. This enabled tracking for the record of students' interaction. The students could ask questions and discuss among their peers and with their instructor through Padlet. The quiz has to be answered before the session, as a post test and after the completion of the GDLM. During this period, participants were allowed to communicate with each if they encountered any problems.

Data were collected from the participant usage and access of the module, as well as the quiz results. The transcript of communication and result of tests would determine the students' understanding. The pre-tests and post-tests results were analysed using paired sample t-tests.

\section{ANALYSIS AND DISCUSSION}

This exploratory implementation study was to determine whether the GDLM based on technology and DHH students' learning styles would improve the DHH learners' comprehension of the graphic design topics. Firstly, an examination of how GDLM based on technology and learning styles is used by the DHH students in the study was done.

\section{Learning with GDLM}

In this module, the first step was to identify the students learning style according to the ILS. There were four dimensions of learning styles and the DHH students had to follow the learning path according to the appropriate learning style. Although the majority of DHH learners have a visual learning style for the input dimension, there was a possibility that they might have "in-between" learning styles as suggested by Felder and Silverman (1988). An ILS score of eleven in one dimension, may indicate a dominant learning style. However, some students have a score of one to five in their learning styles, which probably means the possibility of having two preferred learning styles for a dimension.

In the GDLM, the learners choose the resources based on their learning style, as they had already identified with the Index of Learning Styles (ILS) questions. However, in order to take consideration of these "in between" 
learning styles, students are provided with access to all sources provided in the module should they wish to use them. A sample of the learning styles is seen in Figure 2.

\begin{tabular}{ll}
$\begin{array}{l}\text { Show } 10 \text { entries } \\
\text { NAMA PELAJAR }\end{array}$ & GAYA PEMBELAJARAN \\
\hline Ahmad Baihaqy & Verbal (3), Sekuential (9), Sensori (5), Aktif (5) \\
\hline Albert Tiu & Visual (5), Sekuential (1), Sensori (1), Reklektif (1) \\
\hline Che Mohd Zaizmer & Verbal (7), Sekuential (1), Intuisi (3), Reflektif (9) \\
\hline Hasnin Nabihah & Visual (3), Global (1), Sensori (3), Aktif (3) \\
\hline Ko Zhang Yuan & Verbal (1), Sekuential (1), Sensori (1), Aktif (5) \\
\hline Mohamad Zahirudin & Verbal (1), Global (3), Intuisi (3), Reflektif (1) \\
\hline Ng Cher Yang & Visual (5), Sekuential (7), Sensori (7), Aktif (7) \\
\hline Nur Amalina Abdullah & Verbal (3), Sekuential (1), Sensori (3), Aktif (11) \\
\hline Nur Azlin & Visual (5), Global (3), Sekuential (5), Aktif (1) \\
\hline Nur Najwa & Visual (9), Sekuential (3), Sensori (5), Reflektif (1) \\
\hline Showing 1 to 10 of 25 entries &
\end{tabular}

Fig. 2 - Learning style identification after answering ILS questions

Once learning styles have been identified the student will choose the content sources based on their preferred learning styles. They would be viewing videos and other resources. After completing viewing of resources, either videos or text materials, the learners had to test their understanding by answering the quiz. The questions would be a test of understanding for each topic. The results appeared after the students finished answering all the questions. The students could see the scores of their peers as well in this quiz, and see their ranking in the class. This was intended to motivate the learners. A sample of the quiz is in Figure 3.

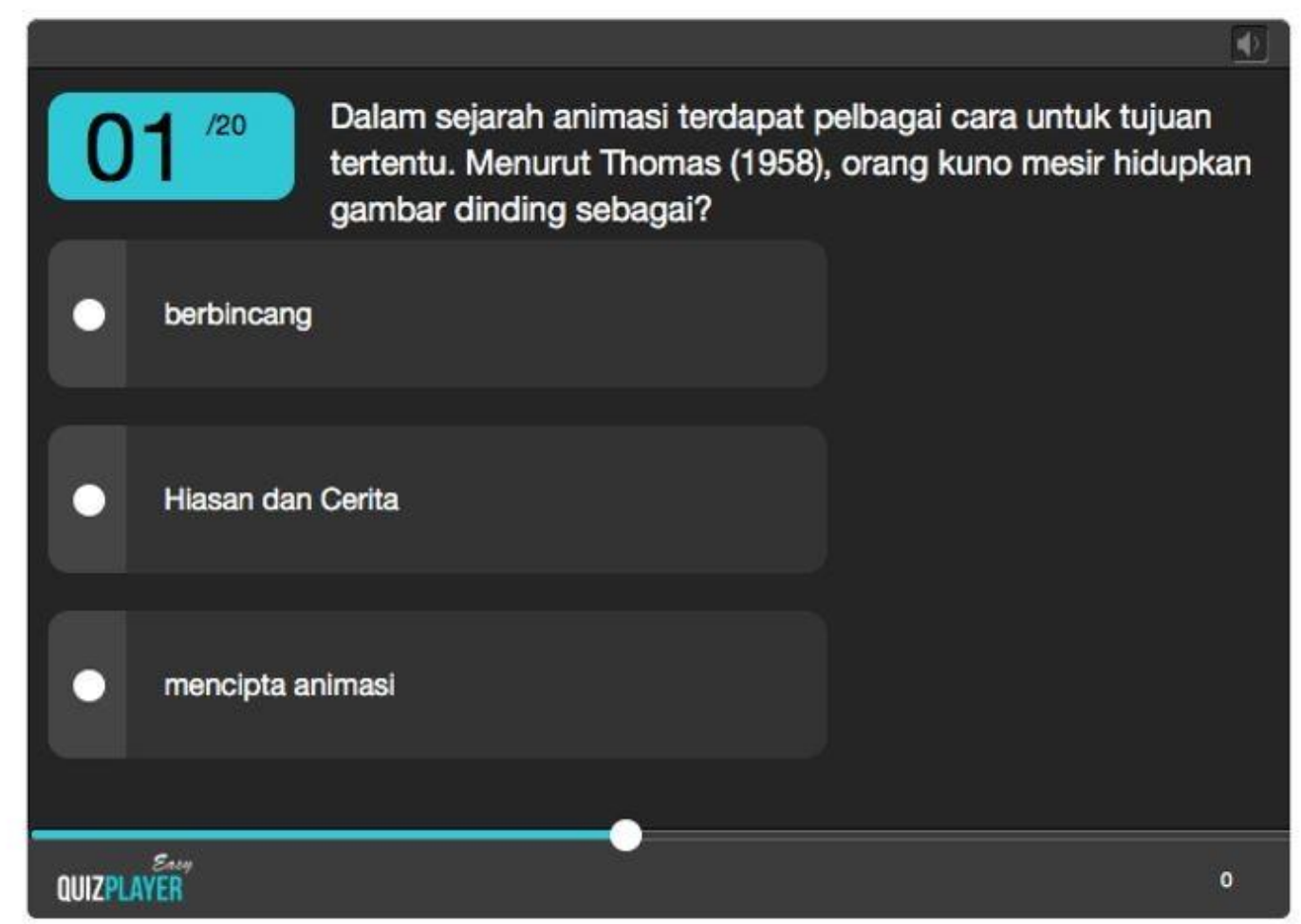

Fig. 3 - Quiz for introduction of graphic animation topic

Learners perceived that the GDLM based on technology and learning styles for the DHH could improve learning. The learners had to go through the content and activities according to their preferred learning styles for better understanding. They interacted and actively participated in the discussions with their peers and instructor as seen in the screen capture of a Padlet discussion (see Figure 4). 


\begin{tabular}{|c|c|c|}
\hline \multicolumn{2}{|c|}{$\begin{array}{l}\text { TOPIK 1: Pengenalan Animasi } \\
\text { Bincang dengan kawan \& pensyarah disini }\end{array}$} & $\Delta$ \\
\hline \multicolumn{2}{|l|}{2 亩 } & a \\
\hline $\begin{array}{l}\text { Semak Markah } \\
\text { Kerja "Word Zomar" siapa? }\end{array}$ & $\begin{array}{l}\text { hi } \\
\text { saya nama ko zhang yuan }\end{array}$ & \\
\hline Kerja "Animasi Komputer" siapa? & //hi Ko Zhang Yuan & 的 \\
\hline & //dah siap & i \\
\hline $\begin{array}{l}\text { chun ren } \\
\text { Tay Chun dan ko Zheng dalam } \\
\text { group }\end{array}$ & group ain \& adlina & ? \\
\hline Ooi Bee Kei dan Tay Tze Qang & $\begin{array}{l}\text { Group Amalina \& Mustaqim } \\
\text { Amalian \& Mustaqim }\end{array}$ & 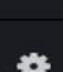 \\
\hline 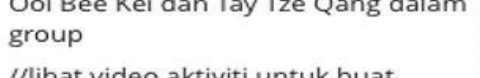 & $\begin{array}{l}\text { //lihat video aktiviti untuk buat } \\
\text { tugasan }\end{array}$ & \\
\hline tugasan & hee kei & \\
\hline $\begin{array}{l}\text { //kalau internet lambat guna video } \\
\text { dalam } C D\end{array}$ & $\begin{array}{l}\text { OOI BEE KEI dan TAY TZE QANG } \\
\text { dalm group }\end{array}$ & \\
\hline Pensyarah & $\begin{array}{l}\text { //lihat video aktiviti untuk buat } \\
\text { tugasan }\end{array}$ & \\
\hline $\begin{array}{l}\text { Guna internet saya } \\
\text { nama: Virus }\end{array}$ & $\begin{array}{l}\text { //kalau internet lambat guna video } \\
\text { dalam CD }\end{array}$ & 3 \\
\hline
\end{tabular}

Fig. 4 - Screen capture of discussion among the DHH students on Padlet

The online interactions were in the Malay language and enabled active learning. According to Felder and Silverman (1988) learners with active learning style under the dimension of process required group discussions for learning as compared to reflective learners, who prefer to work alone and learn independently. DHH learners seemed to be more active learners and preferred the discussion on the interactive wall.

Several challenges were faced during implementation. The module was implemented within learning hours in the computer lab or they can use the module after learning hours at home through their laptops. However, the polytechnic had a poor internet connection at $115 \mathrm{~kb} / \mathrm{s}$. The module was compiled with high quality video and required high speed internet connection for streaming. The researcher provided hotspot facility with an internet provider at $3 \mathrm{Mb} / \mathrm{s}$ speed while in the computer lab and the DHH students had to have their own broadband in order to use the module. Besides that, the researcher provided a DVD to compile the video for their references at home. This condition reduced the communication for using Padlet in their homes.

This study has several limitations. Firstly, the sample size was small as it involved only fifteen DHH students. DHH students were divided into many programs and $15 \mathrm{DHH}$ students registered for the graphic design program. Secondly, the were problems with sufficient devices. Some computers in the computer lab malfunctioned and students were forced to share the computers to use the module. Some students do not have a laptop and used desktop computers at home.

\section{Effectiveness of the GDLM}

In order to determine the effectiveness of the GDLM for learning the topics in graphic design among the DHH students in the context of the study, the results of the pre-test and post-test for each topic were analysed (see Table 1).

Table 1 - Pretest and posttest analysis for each topic

\begin{tabular}{lllll}
\hline Topics & & Mean & N & $\begin{array}{l}\text { Standard } \\
\text { Deviation }(S D)\end{array}$ \\
\hline \multirow{2}{*}{ Introduction of graphic animation } & Post-Test & 13.077 & 15 & 2.660 \\
& Pre-Test & 1.540 & 15 & 1.450 \\
\hline \multirow{2}{*}{ Graphic animation framework } & Post-Test & 15.384 & 15 & 2.218 \\
& Pre-Test & 3.077 & 15 & 1.320 \\
\hline \multirow{2}{*}{ Graphic animation composition } & Post-Test & 15.230 & 15 & 2.773 \\
& Pre-Test & 3.230 & 15 & 2.242 \\
\hline \multirow{2}{*}{ Create graphic animation } & Post-Test & 16.462 & 15 & 2.025 \\
\hline Graphic animation documentation & Pre-Test & 3.846 & 15 & 2.230 \\
\hline
\end{tabular}




$\begin{array}{llll}\text { Pre-Test } & 3.846 & 15 & 2.076\end{array}$

The descriptive statistics showed a large difference between the mean of the pre-test and post-test for each topic. Next, the results of the paired-sample t-test was used to compare the means (See Table 2). There was a significant difference in the mean score between pre-test and post-test for all the topics shows $(p<.05)$.

Table 2 - Paired sample t-test for pretest and posttest by topic

\begin{tabular}{|c|c|c|c|c|c|c|c|}
\hline & & & & $\begin{array}{l}95 \% \text { Different } \\
\text { Interval }\end{array}$ & Confident & & \\
\hline & Mean & $\begin{array}{l}\text { Standard } \\
\text { Deviation } \\
\text { (S.D) }\end{array}$ & $\begin{array}{l}\text { Standard } \\
\text { Error Min }\end{array}$ & Lower & Upper & $\mathbf{t}$ & $\begin{array}{l}\text { Sig. (2- } \\
\text { Tailed) }\end{array}$ \\
\hline $\begin{array}{l}\text { Post-Test } \\
\text { Pre-Test }\end{array}$ & 11.538 & 2.184 & .606 & 10.219 & 12.858 & 19.06 & .000 \\
\hline $\begin{array}{l}\text { Post-Test } \\
\text { Pre-Test }\end{array}$ & 12.308 & 1.797 & .499 & 11.221 & 13.394 & 24.69 & .000 \\
\hline $\begin{array}{l}\text { Post-Test } \\
\text { Pre-Test }\end{array}$ & 12.000 & 1.414 & .392 & 11.145 & 12.855 & 30.59 & .000 \\
\hline $\begin{array}{l}\text { Post-Test } \\
\text { Pre-Test }\end{array}$ & 12.615 & 1.895 & .525 & 11.470 & 13.760 & 24.00 & .000 \\
\hline $\begin{array}{l}\text { Post-Test } \\
\text { Pre-Test }\end{array}$ & 13.692 & 2.810 & .779 & 11.994 & 15.391 & 17.57 & .000 \\
\hline
\end{tabular}

The GDLM seemed to have improved student's understanding as their results seem to significantly improve after using the module. The comparison of mean scores between the topics show that introduction of graphic animation had a lower mean score $(M=13.077, S D=2.660)$ as compared to graphic animation documentation $(M=19.539, S D=2.184)$. This could be because the topic, introduction of graphic animation involves the recall of dates, places and other historical terminology rather than the understanding of concepts, as in the other topics. According to Hamilton (2011) DHH students tend to have limited short-term memory. This may contribute to the difficulty faced in recalling facts.

The findings of the current study suggest that the GLDM is a pomising alternative to support learning of DHH students. As suggested by Bowman and Callan (2012), the selection of relevantpedagogic strategy styles should consider students' background knowledge, capabilities and learning settings in designing a suitable learning content and delivery. In this study, the GDLM not only has addressed their background knowledge and capabilities but also their preferred technological tools and learning styles. Evidently, the improvement in their performance is an indication of the effectiveness of this module to support inclusive learning for the DHH students.

\section{CONCLUSION}

The purpose of this study is to determine whether the GDLM based on technology and DHH students' learning styles would improve the DHH learners' understanding of the graphic design topics in a selected polytechnic. Although most DHH students were visual learners for the perception domain, they may have a different preference for media. This was because not all preferred to watch interpreters on videos as some preferred text input. This may be due to the processing channel preferred and the cognitive load employed (Mayer, 2014). As for the interactions in Padlet, most of the active learners would interact online while reflective learners tended to be observers. Hence, while technology could assist DHH learners, many of them interact according to their preferred learning requirement (Hamilton, 2011). Identification of learning styles does help DHH learners to select appropriate resources to ensure learning (Graf, Kinshuk\& Liu 2009;Larkin-Hein \&Budny, 2001; Mayer, 2003; Naimie, Siraj, Abuzaid, Shagholi, 2010) However, the implementation of the module would be influenced by other factors such as lack of devices for individual learning and lack of internet access.

The use of module in lesson has the potential to enhance DHH students' understanding. The preliminary findings indicate that the module seem to be effective for learning and especially when it was related to conceptual understanding. The preliminary findings indicate that the module could be used for graphic design for the DHH. Instructor acceptance and student acceptance did not seem to be an obstacle to implementing the module. The study is exploratory but it indicates that providing learning module based on technology and DHH learning styles may encourage a better learning experience and enhance understanding. This module may provide a framework to develop other modules for other subject areas for DHH learners. This is to ensure that DHH students have the same access to education as non-DHH learners in line with the Salamanca Statement and Framework for Action on Special Needs Education (SNE) (1994) and the National Education Blueprint (MOE, 2013). 
Further studies in developing other modules for other topics could be conducted with longitudinal studies to determine the effectiveness of the module, as well as qualitative studies for more in-depth investigations before making conclusions on the impact of the module. Studies on the role of instructor, DHH learners and their attitude, motivation, acceptance, interaction and behaviour when using the module could be conducted to provide insights into the implementation and use of the graphic design learning modules based on technology and DHH learning styles. A larger sample could be used for evaluating the module effectiveness. In conclusion, the graphic design learning module can enhance DHH learners' understanding with adaptation of technology and DHH learning styles.

\section{References}

1. Appiah, E. \&Cronjé, J. (2014). The influence of information and communication technology on graphic design: reflections on pedagogy. Journal of Science and Technology, 34/1, pp.85-94. DOI:10.4314/just.v34i1.8

2. Alias, N. (2010). Pembangunan modulpedagogiberasaskanteknologi dan gayapembelajaran FelderSilverman KurikulumFizikSekolahMenengah. (Unpublished Ph.D. Thesis). Universiti Malaya.

3. Alias, R., Alias, N.A., Ibrahim, A.B., Atan, H. \& Kadir, A.L. (2012). What do the disabled students need? A study on the needs of the Special Educational Needs (SEN) learners in Malaysian public universities. The European Journal of Social \&Behaviourial Sciences, 15, pp.602-623. DOI:10.15405/FutureAcademy/ejsbs(2301-2218).2012.3.15

4. Al-Rousan, M., Assaleh, K. \&Tala'a, A. (2009). Video-based Signer-Independent Arabic Sign Language Recognition using Hidden Markov Models. Applied Soft Computing, 9, pp.990-999. DOI:10.1016/j.asoc.2009.01.002

5. Aviles, R. \& Moreno, A. (2010). Creating the condition for educational change: Learning styles and gender. International Journal of Learning and Change, 4/3, pp.252-262. http://dx.doi.org/10.1504/IJLC.2010.035834

6. Barak, A. \&Sadovsky, Y. (2008). Internet use and personal empowerment of hearing-impaired adolescent. Computers in Human Behavior, 24,pp.1802-1815. https://doi.org/10.1016/j.chb.2008.02.007

7. Barca, L., Pezzulo, G., Castrataro, M., Rinaldi, P., \& Caselli, M. (2013). Visual word recognition in Deaf readers: Lexicality is modulated by communication mode. Visual Word Recognition in Deafness, 8/3,pp.1-7. https://doi.org/10.1371/journal.pone.0059080

8. Berent, G., Kelly, R., Schmitz, K. \& Kenny, P. (2008). Visual Input Enhancement via Essay Coding Results in Deaf Learners' Long-Term Retention of Improved English Grammatical Knowledge. Journal of Deaf Studies and Deaf Education, 14,pp.190-204. https://doi.org/10.1093/deafed/enn032

9. Blom, H., Marschark, M., Vervloed, M.P.J. \&Knoors. H. (2014) Finding Friends Online: Online Activities by Deaf Students and Their Well-Being. PLoS ONE, 9/2, e88351. https://doi.org/10.1371/journal.pone.0088351

10. Bottoni, P., Capuano, D., De Marsico, M., Labella, A. \&Levialdi, S. (2011). DELE: A Deaf-centred E-Learning Enviroment. Chiang Mai Journal of Science, 38,pp. 31-57

11. Bower M. (2017). Design of technology-enhanced learning: integrating research and practice. Bingley, UK: Emerald publishing; 2017.

12. Bowman, K. \& Callan, V. J. (2012). A pedagogic framework for socially inclusive VET: principles, strategies and https://www.voced.edu.au/content/ngv\%3A58255

13. Bueno, F.J., Fernández del Castillo, J.R., Garcia, S. \& Borrego, R. (2007). E-learning content adaptation for Deaf students. ACM SIGCSE Bull, 39, pp.271-275.

14. Chowdhuri, D., Parel, N. \&Maity, A. (2012). Virtual cassroom for Deaf people. 2012 IEEE International Conference on Engineering Education: Innovative Practices and Future Trends. New York, NY: Thomson Reuters.

15. Dangsaart, S., Naruedomkul, K., Cercone, N. \&Sirinaovakul, B. (2008). Intelligent Thai TextThai Sign Translation for language learning. Computer \& Education, 51/3,pp.1125-1141.

16. Debevc M, Kosec P, Holzinger A. (2010). Sign Language Interpreter Module: Accessible video retrieval with subtitle. In A. Miesenberger, J. Klaus, W. Zagler\& A. Karshmer (Eds.). LNCS (Lecture Notes in Computer Science), 6180, 221-228

17. Debevc, M., Milošević, D. \&Kožuh, I. (2015) A Comparison of Comprehension Processes in Sign Language Interpreter Videos with or without Captions. PLoS ONE, 10/5, e0127577. DOI:10.1371/journal. pone.0127577

18. DeStefano, D. \& LeFevre, J.A. (2007). Cognitive load in hypertext reading: A review. Computers in Human Behavior, 23, pp.1616-1641. 
19. DeWitt, D., Alias, N., Ibrahim, Z, Ngu, K.S. \&Mohd. Rashid, S.M. (2015). Design of a Learning Module for the DHH in a Higher Education Institution Using Padlet. Procedia Social and Behavioral Sciences, 176, pp.220-226. DOI:10.1016/j.sbspro.2015.01.464.

20. DeWitt, D., Alias, N., Siraj, S. (2014). The design and development of a Collaborative mLearning prototype for Malaysian secondary school science. Educational Technology Research and Development, 62/4,pp.461-480. DOI: 10.1007/s11423-014-9340-y

21. Dunn, R. \& Dunn, K. (1978). Teaching students through their learning style. Reston, VA: ASDC.

22. El Ghoul O, Jemni M. (2009). Multimedia courses generator for deaf children. International Arab Journal of Information Technology, 6/5,pp.458-463.

23. Feenberg, A. (2002). Transforming Technology: A Critical theory revisited. 2nd ed. NY: Oxford University Press.

24. Felder, R. \& Silverman, L. (1988). Learning \& Teaching Styles in Engineering Education. Retrieved from http://www4.ncsu.edu/unity/lockers/users/f/felder/public/Papers/LS-1988.pdf [Accessed 20 June 2020].

25. Felder, R. \&Soloman, B. (1988). Index of Learning Styles. Retrieved from https://educationdesignsinc.com/index-of-learning-styles/ [Accessed 20 June 2020].

26. Fels, D.I., Richards, J., Hardman, J. \& Lee, D. G. (2006). Sign language web pages. American Annals of the Deaf, 151/4,pp.423-433.

27. Franzoni, A. \& Assar, S. (2009). Student learning styles adaptation method based on teaching strategies and electronic media. Educational Technology \& Society, 12/4,pp.15-29.

28. Graf, S., Kinshuk, \& Liu, T. (2009). Supporting teachers in identifying students' learning styles in Learning Management Systems: An automatic student modelling approach. Educational Technology \& Society, 12,pp. 3-14.

29. Gregore, A. (1985). Style Delineator: A self-assessment instrument for adults. Columbia: Gregore Associates.

30. Hall, M. L. \& Bavelier, D. (2010). Working memory, Deafness, and sign language. In M. Marschark\& P. E. Spencer (Eds.). The Oxford handbook of Deaf studies, language, and education, Vol. 2., pp. 458-471. New York, NY: Oxford University Press.

31. Hamilton H. (2011). Memory skills of Deaf learners: Implications and applications. American Annals of the Deaf, 156/4,pp.402-423.

32. Ibrahim, Z., Alias, N., \&Nordin, A.B. (2016). Exploratory Needs Analysis Towards Graphic Design Learning Module Based on Technology \& Learning Styles For Deaf Students. International Educational Technology Conference-IETC 2015, Istanbul, Turkey, May 27-29, 2016.

33. International Labour Organization (ILO) (2012). TVET reform: Designing an inclusive skills development program. Dhaka, Bangladesh: ILO.

34. Knoors, H. \&Hermans, D. (2010). Effective instruction for Deaf and hard-of-hearing students: Teaching strategies, school settings, and student characteristics. In M. Marschark\& P. E. Spencer (Eds.). The Oxford handbook of Deaf studies, language, and education Vol. 2., pp. 57-71. New York, NY: Oxford University Press.

35. Knoors, H. \&Marschark M. (2014). Teaching DHH learners. New York, NY: Oxford University Press.

36. Kuiper, E., Volman, M. \&Terwel, J. (2005). The Web as an Information Resource in K-12 Education: Strategies for supporting students in searching and processing information. Review of Educational Research, 75/3,pp.285-329

37. Larkin-Hein, T. \&Budny, D. (2001). Research on learning style: Applications in Physics and Engineering classroom. Education, 44/1,pp.276-281.

38. Lim, M.Y. (2008). MySlang. An electronic Malaysian sign language dictionary. Kuala Lumpur, Malaysia: University of Malaya.

39. Marschark, M., Sapere, P., Convertino, C. \&Pelz, J. (2008). Learning via direct and mediated instruction by Deaf students. Journal of Deaf Studies and Deaf Education, 13/4,pp.546-561.

40. Mayer, R. (2003). Element of a science of e-learning. Educational Computing Research, 29/3,pp.297-313.

41. Mayer, R. E. (2014). The Cambridge handbook of multimedia learning. New York, NY: Cambridge University Press

42. Mich, O., Pianta, E. \& Mana, N. (2013). Interactive stories and exercises with dynamic feedback for improving reading comprehension skills in Deaf. Computers \& Education, 65, pp.34-44.

43. Ministry of Education (2013). Malaysian Educational Blueprint: Preschool to post-secondary 20132025. Retrieved from https://www.moe.gov.my/menumedia/media-cetak/penerbitan/dasar/1207malaysia-education-blueprint-2013-2025/file [Accessed 20 June 2020]. 
44. Ministry of Higher Education (MOHE) (2014). Malaysian Education Act 1996. Retrieved from http://www.polisas.edu.my/portal/images/stories/Mqa/Akta550.pdf [Accessed 20 June 2020].

45. Nagalingam, V. (2008). Communicative Themes and Features in SMS Messages of the Deaf. Kuala Lumpur: Universiti Malaya. Jabatan Bahasa Inggeris. DOI: 103.5.180.193/kip/Record/um.u765583

46. Naimie, Z., Siraj, S., Abuzaid, R., \&Shagholi, R. (2010). Did you cook based on the right recipe? (Accommodating the student preferences in class). Procedia Social and Behavioral Sciences, 2/2,pp.383-387.

47. Narr, R.\& Cawthon, S. (2011). The "Wh" Question of Visual Phonics: What, Who, Where, When and Why. Journal of Deaf Studies and Deaf Education, 16/1,pp.66-78.

48. Paivo, A. (1986). Mental representations: A dual coding approach. England: Oxford University Press.

49. Pashler, H., McDaniel, M., Rohrer, D. \& Bjork, R. (2008). Learning styles: Concepts and evidence. A Journal of The Association for Psychological Science, 9/3,pp.106-119.

50. Petrantonakis, P., Kosmidou, V., Nikolaraizi, M., Koutsogiorgu, S., Hadjileontiadis, L.J. (2008)."See and See": An Educational Tool for Kids with Hard of Hearing. Eighth IEEE International Conference on Advanced Learning Technologies.

51. Rasch, T. \&Schnotz, W. (2009). Interactive and non-interactive pictures in multimedia learning environments: Effects on learning outcomes and learning efficiency. Learning and Instruction, 19, pp.411-422.

52. Ryan, W. \& Conover, T. (2004). Graphic Communication Today. 4th ed. Clifton Park, NY: Thomson.

53. Saeed, N., Yang, Y., \&Sinnapan, S. (2009). Emerging Web Technologies in Higher Education. A case of incorporating blogs, podcasts and social bookmarks in a Web Programming Course based on Students' learning styles and technology preferences. Educational Technology \& Society, 12/4,pp.98-109.

54. Slavin, R. (1994). Using student team learning. 3rd ed. Baltimore, MD: Johns Hopkins University.

55. Spector, J. M. (2012). Foundations of educational technology. New York, NY: Routledge

56. Stewart, L., Allan, M. \& Harrison, D. (2010). The develoment of a lecture capture system based on a tool to support hearing impaired students. In M. Iskander, V. Kapila, M. Karim M. (Eds.). Technological developments in education and automation, pp. 287-292. Dordrecht: Springer.

57. Stinson M. (2010). Current and future technologies in the education of Deaf students. In $M$. Marschark\& P. Spenser (Eds.). The Oxford handbook of Deaf studies, language, and education Vol. 2. pp. 93-100. New York, NY: Oxford University Press.

58. United Nations Committee on the Rights of Persons with Disabilities (CPRD) (2016). Article 24: Right to inclusive education. from https://tbinternet.ohchr.org/_layouts/15/treatybodyexternal/Download.aspx?symbolno=CRPD/C/ GC/4\&Lang=en

59. UNESCO-UNEVOC (2019). Virtual conference on inclusive TVET: Virtual conference report. Bonn, Germany: UNESCO-UNEVOC.

60. Valentine, G. \& Skelton, T. (2008) Changing spaces: The role of the internet in shaping Deaf geographies. Social and Cultural Geography, 9,pp.469-486.

61. Verhoevan, L. \&Graesser, A. (2008). Cognitive and linguistic factors in interactive knowledge construction. Discourse Processes, 45/4, pp.289-297.

62. Verhoeven, L., Schnotz, W. \& Pass, F. (2009). Cognitive load in interctive knowledge construction. Learning and Instruction, 19/5,pp.369-375.

63. Vrettaros J, Argiri K, Stavrou P, Hrissagis K, Drigas (2010). A. Evaluation Study of Pedagogical Methods and E-Learning Material via Web 2.0 for Hearing Impaired People. Technology Enhanced Learning: Quality of Teaching and Educational Reform, 73,pp.595-601.

64. Yang, F. \& Tsai, C. (2008). Investigating university student preferences and beliefs about learning in the Web-based context. Computer and Education, 50/4,pp.1284-1303.

65. Yong, Y. L. (2007). 3D-Sign-A Computer-Aided Learning Package for Malaysian Sign Language Developed Using 3D Graphics and Animation. Kuala Lumpur, Malaysia: University of Malaya.

66. Zaharudin, R., Nordin, N. \& Yasin, M. (2011). Online ICT-Courses Integrated for the HearingImpaired Individuals' Education: A Preliminary Study from the Students' Perception. Communications in Computer and Information Science, 251, pp.56-63. DOI: 10.1007/978-3-64225327-0 